\title{
Vermogensscheiding door beleggingsondernemingen: een perfecte symbiose van toezichtrecht en civiel recht (I)
}

\author{
Prof. mr. W.A.K. Rank*
}

\begin{abstract}
1 Inleiding
De financiële toezichtwetgeving bevat gedetailleerde regels inzake de door beleggingsondernemingen - bankbeleggingsondernemingen daaronder begrepen - toe te passen vermogensscheiding bij de bewaring van financiële instrumenten en gelden van cliënten. Het gaat hier om regels van toezichtrecht die strekken tot het bereiken van een bepaald civielrechtelijk gevolg, namelijk dat activa van cliënten zodanig zijn afgescheiden van het vermogen van de beleggingsonderneming dat (andere) crediteuren van de beleggingsonderneming dan de rechthebbenden zich daarop niet kunnen verhalen in het geval van insolventie van de beleggingsonderneming. ${ }^{1}$ Hoofddoel is bescherming tegen het tussenpersoonrisico, het zogenaamde intermediary risk. ${ }^{2} \mathrm{Om}$ het beoogde civielrechtelijke gevolg te bereiken zijn civielrechtelijke regels of civielrechtelijke constructies vereist. $Z$ ijn deze civielrechtelijke regels en civielrechtelijke constructies vooral van nationale origine, de toezichtrechtelijke regels hebben in overwegende mate een Europese herkomst. Daarbij gaat het soms om richtlijnen die in het Nederlandse recht zijn geïmplementeerd en soms om verordeningen met rechtstreekse werking in Nederland. Met de komst van MiFID II, EMIR en de CSD-verordening is de toezichtrechtelijke regeling van de vermogensscheiding in ieder geval op een aantal punten gewijzigd. Dit vormt een mooie aanleiding om de beide typen regels te bespreken en te bezien hoe zij zich tot elkaar verhouden en op elkaar inwerken.
\end{abstract}

Prof. mr. W.A.K. Rank is hoogleraar Financieel Recht aan de Universiteit Leiden en Of Counsel bij NautaDutilh te Amsterdam.

1. Zie over vermogensscheiding bij beleggingsondernemingen onder MiFID I uitvoerig: W.A.K. Rank, Vermogensscheiding, in: D. Busch \& C.M. Grundmann-van de Krol (red.), Handboek beleggingsondernemingen (Serie Onderneming en Recht, deel 51), Deventer: Kluwer 2009, p. 509-539 en voor diverse bijdragen van diverse auteurs uit verschillend perspectief: W.A.K. Rank (red.), Vermogensscheiding in de financiële praktijk (Bankjuridische reeks 56), Amsterdam: NIBE-SVV 2008.

2. Zie over intermediary risk in breed verband: S.L. Schwarcz, Intermediary Risk in a Global Economy, Duke Law Journal (50) 2001, afl. 6, p. 1541-1607.
In essentie wijkt de regeling van de vermogensscheiding in MiFID II niet materieel af van die in MiFID. Wel behelzen MiFID II en de (Level 2) MiFID II-Uitvoeringsrichtlijn nieuwe bepalingen met betrekking tot het aangaan door beleggingsondernemingen van effectenfinancieringstransacties en financiëlezekerheidsovereenkomsten (FZO's) met cliënten. Deze nieuwe bepalingen houden verband met de regeling van de vermogensscheiding omdat bij dergelijke overeenkomsten de eigendom van het onderpand overgaat van de cliënt op de beleggingsonderneming. Daarnaast zijn onder MiFID II de bepalingen inzake de bij de bewaring van financiële instrumenten en gelden in acht te nemen informatieverplichtingen niet langer opgenomen in de Uitvoeringsrichtlijn, maar in de (Level 2) MiFID II-Uitvoeringsverordening 2017/565. Voor zover het gaat om het afscheiden van derivatenposities vormen de nationale regels niet alleen de implementatie van de in MiFID II vervatte regels inzake vermogensscheiding, maar strekken zij er eveneens toe om de Nederlandse wetgeving in de pas te laten lopen met de in EMIR neergelegde regels inzake (administratieve) segregatie en portabiliteit.

Waar het gaat om financiële instrumenten zijn de toezichtrechtelijke regels inzake vermogensscheiding niet beperkt tot effecten in de klassieke zin des woords. $\mathrm{Zij}$ hebben betrekking op alle financiële instrumenten. $\mathrm{Zij}$ verplichten derhalve ook tot een afscheiding van voor cliënten gehouden derivatenposities. Het gaat daarbij uitsluitend om derivaten waarbij de beleggingsonderneming handelt als tussenpersoon. Alleen als de beleggingsonderneming handelt als tussenpersoon is sprake van het houden van financiële instrumenten voor een cliënt en van intermediary risk. Als de beleggingsonderneming niet handelt als tussenpersoon maar als wederpartij, is geen sprake van het houden van posities voor een cliënt en zijn de vermogens- 


\section{Maandblad Vermogensrecht}

scheidingsregels niet van toepassing. ${ }^{3}$ Van een handelen als tussenpersoon is altijd sprake bij beursverhandelde derivaten. ${ }^{4}$ Bij OTC-derivaten handelt de beleggingsonderneming meestal niet als intermediair maar als wederpartij. Dat neemt niet weg dat ook bij OTC-derivaten een handelen als tussenpersoon tot de mogelijkheden behoort.

Bij vermogensscheiding gaat het steeds om juridische segregatie. Deze vorm van segregatie moet worden onderscheiden van administratieve segregatie. In het geval van juridische segregatie zijn de voor een cliënt gehouden waarden afgescheiden van de waarden van de intermediair zelf en van die van andere clienten. De waarden behoren dan in juridische zin toe aan de cliënt of zijn uitsluitend vatbaar voor verhaal door de cliënt en zijn niet vatbaar voor verhaal door (andere) crediteuren van de intermediair. In het geval van administratieve segregatie zijn de voor een cliënt gehouden activa alleen operationeel afgescheiden van de posities van de financiële onderneming zelf en mogelijk van die van andere cliënten van de financiële onderneming. Deze vorm van segregatie vinden we onder meer in EMIR en de CSD-verordening. EMIR legt administratieve segregatieverplichtingen op aan CCPs en CMs (en zelfs aan cliënten van $\mathrm{CMs}$ ), terwijl de CSD-verordening administratieve segregatieverplichtingen oplegt aan CSDs en aangesloten instellingen. ${ }^{5}$ Overigens is administratieve segregatie niet zelden een voorwaarde voor juridische segregatie. Om juridische afscheiding mogelijk te maken zal de financiële onderneming haar administratie immers op een zodanige wijze moeten voeren dat daaruit blijkt welke financiële instrumenten en gelden voor welke cliënten worden gehouden. ${ }^{6}$

Omdat wij in Nederland niet beschikken over de figuur van de trust, waarbij de activa niet in het vermogen van de juridische eigenaar vallen maar in dat van de begunstigde, zijn er naar

3. Zie M.G.C.M. Peeters \& W.A.K. Rank, Bescherming van rechten van derivatencliënten bij insolventie van een intermediair, in: S.E. Bartels e.a. (red.), Effecten en vermogensrecht (Serie Onderneming en Recht, deel 63), Deventer: Kluwer 2011, p. 137-176, in het bijzonder p. 139-141. Zie voorts over mogelijke wijzen van bescherming van derivatenbeleggers: E.W. Kuijper, Een fail-safe systeem in beleggersland?, Utrecht 2010, m.n. p. 83 e.v., en A.A. van Angeren \& R.K. Bonhof, Vermogensscheiding voor derivaten - lastig maar niet onmogelijk, in: F.G.B. Graaf, R.H. Maatman \& L.J. Silverentand (red.), Gedurfde essays over financieel toezichtrecht. Lustrumbundel 2012, Vereniging voor Effectenrecht (Serie vanwege het Van der Heijden Instituut, deel 113), Deventer: Kluwer 2012, p. 231-246.

4. Schrijver dezes wees al in 1997 op het feit dat de vermogensscheidingsregels ook voor beursverhandelde derivaten gelden, maar was toen nog een roepende in de woestijn: W.A.K. Rank, Bewaring en eigendom van effecten (preadvies Vereniging voor Effectenrecht 1996), Deventer: Kluwer 1997, p. 65; zie ook W.A.K. Rank, Vermogensscheiding bij opties, in: S.C.J.J. Kortmann e.a. (red.), Vertegenwoordiging en tussenpersonen (Serie Onderneming en Recht, deel 17), Deventer: Kluwer 1999, p. 267-305.

5. De begrippen CCP, CM en CSD worden gedefinieerd en besproken in par. 2.4 en 2.5 .

6. Zie W.A.K. Rank, Segregatie en portabiliteit: de Wge als panacee voor MiFID en EMIR, MvV 2014, afl. 7/8, p. 214-223 (hierna: Rank 2014a); W.A.K. Rank \& S. Uiterwijk, Voorgestelde wijziging segregatie EMIR: een (ondoordacht) steuntje in de rug voor portabiliteit, FR 2017, afl. 9, p. 374-380.
Nederlands recht bepaalde constructies nodig om vermogensscheiding van niet-geïndividualiseerde activa te realiseren. ${ }^{7} \mathrm{De}$ meest gebruikelijke - en door de wetgever als geldig erkende constructies die in dit verband worden gehanteerd, zijn (a) het onderbrengen van de activa in een aparte (bewaar)instelling en (b) het creëren van een afgescheiden vermogen bij de beleggingsonderneming zelf. ${ }^{8}$ Voor dit laatste is sinds het ProCallarrest van de Hoge Raad in beginsel een wettelijke regeling nodig. ${ }^{9}$ De keerzijde van vermogensscheiding - het apart zetten van bepaalde vermogensbestanddelen ten behoeve van bepaalde crediteuren - is immers dat er inbreuk wordt gemaakt op twee belangrijke vermogensrechtelijke principes, te weten (1) het principe dat een schuldeiser zijn vordering op alle goederen van zijn schuldenaar kan verhalen (art. 3:276 van het Burgerlijk Wetboek (BW)), en (2) de paritas creditorum, het beginsel dat schuldeisers onderling een gelijk recht hebben om zich naar evenredigheid van hun vordering op de goederen van hun schuldenaar te verhalen (art. 3:277 BW). Deze beginselen zijn zo wezenlijk dat partijen daaraan niet voorbij moeten kunnen gaan door middel van een simpele contractuele regeling.

Voor beleggingsondernemingen behoren beide constructies tot de mogelijkheden: bewaring van activa van cliënten via een separate (bewaar)instelling en de creatie van afgescheiden (verhaals)vermogens door het bewaren van de relevante activa conform de Wet giraal effectenverkeer (Wge). Om meer beleggers te laten profiteren van de laatstgenoemde vorm van bescherming is de Wge op 1 januari 2011 ingrijpend gewijzigd. ${ }^{10}$ Met deze wijziging is ten aanzien van effecten in de klassieke zin des woords voorzien in een substantiële uitbreiding van het toepassingsgebied van de Wge. Vervolgens is de Wge op 1 april 2016 nog een keer ingrijpend gewijzigd. Bij die

7. Vgl. E. Schmieman, In Christel we trust. Een (Nederlandse) trust als mogelijke oplossing voor vermogensscheiding bij derivaten, in: D. Busch e.a. (red.), Christels koers. Liber amicorum Prof. mr. drs. C.M. Grundmann-van de Krol (Serie Onderneming en Recht, deel 79), Deventer: Kluwer 2013, p. 609-628.

8. Zie over het wezen van een afgescheiden vermogen: N.E.D. Faber, Eigendom ten titel van beheer, kwaliteitsrekening en afgescheiden vermogen, in: D. Hayton e.a. (red.), Vertrouwd met de trust (Serie Onderneming en Recht, deel 5), Deventer: Kluwer 1996, p. 197-199. Andere mogelijke constructies zijn de vestiging van een pandrecht op de activa ten behoeve van de cliënten tot zekerheid van de rechten van deze cliënten met betrekking tot deze activa of een regeling die de cliënt bij faillissement van de financiële onderneming de mogelijkheid geeft de rechten die de financiële onderneming ter zake van de activa jegens een derde heeft op de cliënt te doen overgaan. Vgl. art. 7:420 BW.

9. HR 13 juni 2003, NJ 2004/196 (Beatrix Ziekenhuis/ProCall). Zo ook W. Snijders, Nog een duit in het zakje van de trust, in: S.C.J.J. Kortmann e.a. (red.), Onderneming en 5 jaar nieuw burgerlijk recht (Serie Onderneming en Recht, deel 7), Deventer: Kluwer 1997, p. 94-96. Zie echter HR 23 juni 2017, ECLI:NL:HR:2017:1139 (St. Beheer Derdengelden Advocatuur NautaDutilh /Ontvanger), waarin de Hoge Raad, zonder dat daarvoor enige wettelijke basis bestaat, aanneemt dat een banksaldo ten name van een stichting derdengelden advocatuur toebehoort aan de gezamenlijke cliënten van het advocatenkantoor, naar evenredigheid van de ten behoeve van deze cliënten gestorte bedragen, en niet aan de stichting, waarover (terecht) kritisch: R.M. Wibier, De moeilijke verhouding tussen het Nederlandse recht en de trust, AA 2017, afl. 9, p. 707-709.

10. Kamerstukken II 2008/09, 31830, 1-4. 
gelegenheid is een regeling strekkende tot afscheiding van voor cliënten gehouden derivatenposities aan de wet toegevoegd. ${ }^{11}$

In dit - in twee delen te verschijnen - artikel zullen de regels inzake vermogensscheiding bij beleggingsondernemingen op een rijtje worden gezet en geanalyseerd. In dat verband zal eerst worden ingegaan op de relevante toezichtrechtelijke regels (par. 2 en 3). Daarbij wordt aandacht besteed aan zowel de Europese toezichtregelgeving inzake vermogensscheiding (par. 2) als de Nederlandse toezichtregelgeving op dit punt (par. 3). Uitgangspunt is daarbij het regelgevend kader zoals dat thans luidt op basis van MiFID II/MiFIR (par. $2.1 \mathrm{t} / \mathrm{m}$ 2.3), EMIR (par. 2.4) en de CSD-verordening (par. 2.5) respectievelijk de Wft (par. 3.1), het Bgfo Wft (par. 3.2) en de NRgfo Wft (par. 3.3). Bij het bespreken van de NRgfo Wft wordt onderscheiden tussen niet-bankbeleggingsondernemingen (par. 3.3.1) en bankbeleggingsondernemingen (par. 3.3.2). Vervolgens worden de verschillende constructies bekeken vanuit een civielrechtelijk perspectief (par. 4 en 5). Het gaat daarbij steeds om structuren die door het toezichtrecht worden gefaciliteerd en gereguleerd, maar door het civiele recht worden gecreëerd en geïmplementeerd. Aan de orde komen in dit verband bewaring via de Wge (par. 4) en bewaring via een bewaarinstelling (par. 5). Bij bewaring via de Wge wordt onderscheiden tussen de regeling voor effectenbeleggers (par. 4.2) en die voor derivatenbeleggers (par. 4.3). Bij het bespreken van de civielrechtelijke aspecten wordt in het bijzonder ingegaan op de rechten van cliënten ten aanzien van door hen bij de (bank)beleggingsonderneming in bewaring gegeven financiële instrumenten en gelden in het geval van insolventie van de (bank)beleggingsonderneming. ${ }^{12}$ Het artikel wordt afgesloten met een samenvatting en een conclusie over de merites van het bestaande duale regime (par. 6).

In verband met de omvang wordt dit artikel in twee delen gepubliceerd. Dit eerste deel betreft naast de inleiding (par. 1) een beschrijving van de Europese toezichtregels op het punt van de vermogensscheiding (par. 2). Het tweede deel - te verschijnen in MvV 2018, afl. 6 - beschrijft de Nederlandse toezichtregels en de privaatrechtelijke regeling van de vermogensscheiding en hoe de beide soorten rechtsregels zich tot elkaar verhouden (par. $3 \mathrm{t} / \mathrm{m} 5$ ). Dit deel bevat ook de samenvatting en de conclusie (par. 6). Omdat sprake is van één geïntegreerd artikel zijn de paragrafen en subparagrafen van de beide delen doorlopend genummerd.

11. Kamerstukken II $2014 / 15,34198,1-4$

12. Zie voor uitvoeriger beschouwingen over de bewaarsituatie bij banken: Rank 1997; B.F.L.M. Schim, Giraal effectenverkeer en goederenrecht (Serie Onderneming en Recht, deel 36), Deventer: Kluwer 2006; M. Haentjens, Harmonisation of Securities Law: Custody and Transfer of Securities in European Private Law, Alphen aan den Rijn: Kluwer Law International 2007.

\section{Europese toezichtregelgeving}

\subsection{Europese toezichtregelgeving vermogensscheiding: MiFID II}

De regels inzake de vermogensscheiding bij beleggingsondernemingen vinden hun basis primair in Europese regelgeving, eerst in art. 10 ISD, ${ }^{13}$ later in art. 13 lid 7 en $8 \mathrm{MiFID}^{14}$ en thans in art. 16 lid $8 \mathrm{t} / \mathrm{m} 10$ MiFID II. ${ }^{15}$ Op grond van art. 10 ISD diende elke lidstaat toezichtrechtelijke regels op te stellen die een beleggingsonderneming zouden verplichten adequate regelingen te treffen met betrekking tot (a) financiële instrumenten van beleggers ter vrijwaring van hun eigendomsrechten, met name in het geval van insolventie van de beleggingsonderneming, en om te voorkomen dat deze financiële instrumenten door de beleggingsonderneming voor eigen rekening worden gebruikt, tenzij met uitdrukkelijke instemming van de beleggers, en (b) gelden van beleggers ter vrijwaring van hun rechten en om, behalve in het geval van bankbeleggingsondernemingen, te voorkomen dat gelden van beleggers door de beleggingsonderneming voor eigen rekening worden gebruikt. Art. 13 lid 7 en 8 MiFID bevatte een gelijkluidende algemene verplichting tot het treffen van adequate maatregelen ter bescherming van de rechten van cliënten ten aanzien van door hen bij een beleggingsonderneming in bewaring gegeven financiële instrumenten en gelden en een gelijkluidend algemeen verbod op het gebruik voor eigen rekening door de beleggingsonderneming van financiële instrumenten en gelden van cliënten. Deze bepalingen werden nader uitgewerkt in art. $16 \mathrm{t} / \mathrm{m}$ 20 MiFID-Uitvoeringsrichtlijn. ${ }^{16}$ De in art. 19 lid 3 MiFID vervatte algemene verplichting om cliënten te informeren omtrent de aan hen te verlenen diensten en de daaraan verbonden risico's werd ten aanzien van de bewaring van financiele instrumenten en gelden van cliënten uitgewerkt in art. 32 MiFID-Uitvoeringsrichtlijn.

De regels van art. 13 lid 7 en 8 MiFID zijn thans te vinden in art. 16 lid 8 en 9 MiFID II - in dezelfde bewoordingen - en worden nader uitgewerkt in art. 2 t/m 8 MiFID II-Uitvoe-

13. Richtlijn 93/22/EEG van de Raad van 10 mei 1993 betreffende het verrichten van diensten op het gebied van beleggingen in effecten, PbEG 11 juni 1993, L 141/27.

14. Richtlijn 2004/39/EG van het Europees Parlement en de Raad van 21 april 2004 betreffende markten voor financiële instrumenten, tot wijziging van de Richtlijnen 85/611/EEG en 93/6/EEG van de Raad en van Richtlijn 200/12/EG van het Europees Parlement en de Raad en houdende intrekking van Richtlijn 93/22/EEG van de Raad, PbEU 30 april 2004, L 145/1.

15. Richtlijn 2014/65/EU van het Europees Parlement en de Raad van 15 mei 2014 betreffende markten voor financiële instrumenten en tot wijziging van Richtlijn 2002/92/EG en Richtlijn 2011/61/EU, PbEU 12 juni 2014, L 173/349. Zie ook M. Haentjens \& W.A.K. Rank, Legal and Operational Segregation of Securities, Derivatives and Cash, in: M. Haentjens \& B. Wessels (red.), Crisis Management in the Banking Sector, Cheltenham: Edward Elgar 2015, p. 366 e.v.

16. Richtlijn 2006/73/EG van de Commissie van 10 augustus 2006 tot uitvoering van Richtlijn 2004/39/EG van het Europees Parlement en de Raad wat betreft de door beleggingsondernemingen in acht te nemen organisatorische eisen en voorwaarden voor de bedrijfsuitoefening en wat betreft de definitie van begrippen voor de toepassing van genoemde richtlijn, PbEU 2 september 2006, L 241/26. 
ringsrichtlijn. ${ }^{17}$ Nieuw is de bepaling van art. 16 lid 10 MiFID II. Deze bepaling voorziet in een verbod op het aangaan door een beleggingsonderneming van een FZO tot overdracht met een niet-professionele cliënt ter securering van huidige of toekomstige verplichtingen van een dergelijke cliënt jegens de beleggingsonderneming. Deze bepaling wordt uitgewerkt in art. 5 lid 5 MiFID II-Uitvoeringsrichtlijn. Onder een beleggingsonderneming moet ook worden begrepen een bank die beleggingsdiensten verleent. Dit betekent in de praktijk bijvoorbeeld dat een bank die met een niet-professionele cliënt in derivaten handelt, de aan de bank als onderpand te verschaffen gelden en/of effecten niet meer in eigendom zal mogen verkrijgen. De bank zal deze gelden en/of effecten dus niet meer ten titel van overdracht mogen (doen) bijschrijven op een rekening op naam van de bank en zal moeten opteren voor een andere vorm van zekerheid. Een FZO-pandrecht ligt in dit verband het meest in de rede. ${ }^{18}$ De verplichting tot informatieverschaffing vinden we thans in art. 24 lid 4 MiFID II. Ten aanzien van de bewaring van financiële instrumenten en gelden van cliënten is deze verplichting concreet uitgewerkt in art. 49 MiFID II-Uitvoeringsverordening 2017/565. ${ }^{19}$

\subsection{Europese toezichtregelgeving vermogensscheiding: MiFID II-Uitvoeringsrichtlijn}

Art. 2 MiFID II-Uitvoeringsrichtlijn wijkt niet materieel af van art. 16 MiFID-Uitvoeringsrichtlijn. Art. 2 lid 1 MiFID IIUitvoeringsrichtlijn verplicht de lidstaten om te bepalen dat een beleggingsonderneming alle gegevens en rekeningen moet bijhouden die noodzakelijk zijn om haar op elk moment onmiddellijk in staat te stellen de financiële instrumenten en gelden die voor een cliënt worden aangehouden, te onderscheiden van voor andere cliënten aangehouden financiële instrumenten en gelden en haar eigen financiële instrumenten en gelden. Deze gegevens moeten zo worden bijgehouden dat deze altijd accuraat zijn en in elk geval de voor cliënten aangehouden financiële instrumenten en gelden weerspiegelen en als controlespoor kunnen dienen. De beleggingsonderneming moet op gezette tijden nagaan of de bedoelde gegevens en rekeningen overeenstemmen met die van eventuele derden door wie deze financiële instrumenten en gelden worden aangehouden. Verder dient de beleggingsonderneming ervoor te zorgen dat financiële instrumenten van cliënten die bij een

17. Gedelegeerde Richtlijn (EU) 2017/593 van de Commissie van 7 april 2016 houdende aanvulling van Richtlijn 2014/65/EU van het Europees Parlement en de Raad met betrekking tot de bescherming van financiële instrumenten en geldmiddelen die cliënten toebehoren, productgovernanceverplichtingen en de regels die van toepassing zijn op het betalen of het ontvangen van provisies, commissies en geldelijke of niet-geldelijke tegemoetkomingen, PbEU 31 maart 2017, L 87/500-517.

18. Zie over dit verbod en de consequenties ervan voor de praktijk uitvoerig: W.A.K. Rank \& S. Uiterwijk, Verbod op FZO tot overdracht onder MiFID II: van zekerheidseigendom naar pandrecht?, FR 2018, afl. 1/2, p. 39-46.

19. Gedelegeerde Verordening (EU) 2017/565 van de Commissie van 25 april 2016 houdende aanvulling van Richtlijn 2014/65/EU van het Europees Parlement en de Raad wat betreft de door beleggingsondernemingen in acht te nemen eisen en voorwaarden voor de bedrijfsuitoefening en wat betreft de definitie van begrippen voor de toepassing van genoemde richtlijn, PbEU 31 maart 2017, L 87/1. derde worden aangehouden, kunnen worden onderscheiden van de financiële instrumenten die aan de beleggingsonderneming zelf toebehoren en van de financiële instrumenten die aan de derde toebehoren.

Dit dient te geschieden door het aanhouden van verschillend getitelde rekeningen in de boeken van de derde of door andere gelijkwaardige maatregelen waarmee hetzelfde beschermingsniveau wordt bereikt. Een soortgelijke verplichting geldt ten aanzien van door de beleggingsonderneming aangehouden gelden van cliënten. Het gaat daarbij om gelden die overeenkomstig art. 4 MiFID II-Uitvoeringsrichtlijn zijn gedeponeerd bij een centrale bank, een bank of een erkend geldmarktfonds. Ook moet de beleggingsonderneming worden verplicht tot het treffen van passende organisatorische maatregelen om het risico van verlies van de financiële instrumenten of gelden tot een minimum te beperken. Als deze administratieve segregatie naar het recht van de desbetreffende lidstaat of het recht van het land waar de financiële instrumenten of gelden worden aangehouden, niet tot juridische segregatie leidt, moet de desbetreffende lidstaat op grond van art. 2 lid 2 en 3 MiFID IIUitvoeringsrichtlijn zodanige maatregelen aan beleggingsondernemingen opleggen dat dit resultaat wel wordt bereikt.

Nieuw is de bepaling van art. 2 lid 4 MiFID II-Uitvoeringsrichtlijn. Dit artikellid verplicht de lidstaten ervoor te zorgen dat goederenrechtelijke zekerheidsrechten, voorrechten of rechten van verrekening ten aanzien van financiële instrumenten of gelden van cliënten die een derde in staat stellen zich op die financiële instrumenten of gelden te verhalen voor schulden die geen betrekking hebben op de cliënt, niet zijn toegestaan, tenzij de wetgeving in het land waar de financiële instrumenten of gelden worden aangehouden daartoe verplicht. De beleggingsonderneming dient de cliënt te informeren over door haar met derden gesloten overeenkomsten waarbij dergelijke rechten met betrekking tot voor de cliënt gehouden activa tot stand worden gebracht, en dient de cliënt te wijzen op de risico's van dergelijke regelingen. Van dergelijke regelingen moet melding worden gemaakt in de contracten met de cliënt en in de eigen rekeningen van de beleggingsondernemingen. Uiteraard staat het de beleggingsonderneming vrij de derde een goederenrechtelijk zekerheidsrecht, voorrecht of verrekeningsrecht te verlenen met betrekking tot haar eigen activa.

Nieuw is overigens ook art. 2 lid 5 MiFID II-Uitvoeringsrichtlijn. Deze bepaling draagt de lidstaten op ervoor te zorgen dat beleggingsondernemingen in het geval van insolventie informatie met betrekking tot financiële instrumenten en gelden van cliënten ter beschikking stellen van de bevoegde toezichthoudende autoriteiten en van curatoren, bewindvoerders en vereffenaars.

Art. 3 MiFID II-Uitvoeringsrichtlijn betreft de voorwaarden waaronder een beleggingsonderneming financiële instrumenten van cliënten mag aanhouden bij een derde. Dit artikel wijkt niet materieel af van de bepaling van art. 17 MiFID-Uit- 
voeringsrichtlijn. Allereerst dient de beleggingsonderneming bij de aanwijzing van een dergelijke derde de nodige bekwaamheid, zorgvuldigheid en waakzaamheid toe te passen. Daarbij dient de beleggingsonderneming rekening te houden met de deskundigheid en marktreputatie van de betrokken derde, evenals met alle op het aanhouden van deze financiële instrumenten betrekking hebbende wettelijke verplichtingen of marktpraktijken die de rechten van de cliënt nadelig kunnen beïnvloeden. Indien in het rechtsgebied waar de beleggingsonderneming de financiële instrumenten wil aanhouden het bewaren van financiële instrumenten voor rekening van anderen onderworpen is aan specifieke regelgeving, brengt de beleggingsonderneming deze financiële instrumenten alle onder bij een derde die aan het toezicht op de naleving van deze regels is onderworpen. Ten slotte houdt een beleggingsonderneming financiële instrumenten niet voor een cliënt aan bij een derde in een niet-EU/EER-lidstaat waar het aanhouden en bewaren van financiële instrumenten voor rekening van een andere persoon niet is gereguleerd, tenzij (a) de aard van de financiële instrumenten of van de te verlenen beleggingsdiensten vereist dat ze bij een derde in dat land worden aangehouden, of (b) het financiële instrumenten betreft die voor een zakelijke client worden aangehouden en deze daarom schriftelijk heeft verzocht.

Art. 4 MiFID II-Uitvoeringsrichtlijn heeft betrekking op door een beleggingsonderneming van cliënten ontvangen gelden. Deze bepaling herhaalt voornamelijk wat eerder in art. 18 MiFID-Uitvoeringsrichtlijn stond. Het artikel onderscheidt tussen beleggingsondernemingen met en zonder een bankvergunning. Betreft het een niet-bankbeleggingsonderneming, dan moeten deze gelden ingevolge art. 4 lid 1 MiFID II-Uitvoeringsrichtlijn onmiddellijk worden gestort op één of meer rekeningen ten name van de cliënt bij een centrale bank, een bank of een erkend geldmarktfonds, bij de selectie, aanwijzing en periodieke beoordeling van welke bank of erkend geldmarktfonds de beleggingsonderneming de nodige bekwaamheid, zorgvuldigheid en waakzaamheid moet toepassen. Daarbij dient de beleggingsonderneming rekening te houden met de deskundigheid en marktreputatie van de betrokken derde, evenals met alle op het aanhouden van deze financiële instrumenten betrekking hebbende wettelijke verplichtingen of marktpraktijken die de rechten van de cliënt nadelig kunnen beïnvloeden. Deze verplichting geldt niet voor bankbeleggingsondernemingen. Als vergunninghoudende bank is een dergelijke beleggingsonderneming zonder meer bevoegd gelden voor cliënten onder zich te houden.

Art. 5 MiFID II-Uitvoeringsrichtlijn bevat niet heel veel nieuws ten opzichte van art. 19 MiFID-Uitvoeringsrichtlijn. Ingevolge deze bepaling is het aangaan door een beleggingsonderneming van effectenfinancieringstransacties met betrekking tot door haar voor een cliënt gehouden financiële instru- menten alleen toegestaan binnen strikte grenzen. ${ }^{20}$ Het artikel bepaalt dat een beleggingsonderneming alleen dergelijke transacties mag aangaan met betrekking tot financiële instrumenten die zij voor een cliënt aanhoudt, indien (a) de cliënt vooraf uitdrukkelijk heeft ingestemd met een dergelijke handelwijze en met de voorwaarden waaronder een en ander zal plaatsvinden, welke instemming moet blijken uit geschreven stukken en door een handtekening moet zijn bevestigd, en (b) dit uitsluitend geschiedt met inachtneming van genoemde voorwaarden. Nieuw is dat de verplichting van een handtekening thans ook geldt voor professionele cliënten. Identieke voorwaarden gelden voor het aangaan van effectenfinancieringstransacties met betrekking tot financiële instrumenten die een beleggingsonderneming voor een cliënt op een omnibusrekening bij een derde aanhoudt. ${ }^{21}$ Bovendien dient de beleggingsonderneming in dat geval te beschikken over systemen en controlemiddelen die waarborgen dat de betrokken financiële instrumenten toebehoren aan cliënten die vooraf uitdrukkelijk hun instemming hebben verleend.

Nieuw ten opzichte van art. 19 MiFID-Uitvoeringsrichtlijn is dat art. 5 MiFID II-Uitvoeringsrichtlijn bepaalt dat de lidstaten ervoor dienen te zorgen dat beleggingsondernemingen passende maatregelen kunnen nemen ter voorkoming van niettoegestaan gebruik van financiële instrumenten van cliënten. Het artikel noemt in dit verband het sluiten van een overeenkomst met de cliënt, waarin is opgenomen welke maatregelen de beleggingsonderneming kan nemen als de cliënt op de datum van afwikkeling onvoldoende financiële instrumenten op zijn rekening heeft. Daarbij wordt gerefereerd aan het opnemen van leningen of het liquideren van de positie. Verder dient de beleggingsonderneming nauwlettend te monitoren dat op de datum van afwikkeling daadwerkelijk kan worden geleverd en, indien dit niet mogelijk is, maatregelen te treffen om een non-settlement te voorkomen. Daarnaast dient zij de uitstaande effecten nauwlettend te monitoren en tijdig op te vragen. Ten slotte dient de beleggingsonderneming ervoor te zorgen dat door of ten behoeve van de wederpartij bij de effectenfinancieringstransactie passende zekerheden worden verschaft ter securering van haar verplichting tot teruglevering van gelijksoortige financiële instrumenten.

Art. 5 lid 5 MiFID II-Uitvoeringsrichtlijn werkt het verbod op het aangaan door beleggingsondernemingen van FZO's tot

20. Art. 5 MiFID II-Uitvoeringsrichtlijn spreekt van effectenfinancieringstransacties. Dit begrip wordt gedefinieerd in art. 1 Uitvoeringsrichtlijn en wel door een verwijzing naar de definitie in art. 3 onderdeel 11 van Verordening (EU) 2015/2365 van het Europees Parlement en de Raad van 25 november 2015 betreffende de transparantie van effectenfinancieringstransacties en van hergebruik en tot wijziging van Verordening (EU) 648/2012, PbEU 23 december 2015, L 337/1. Blijkens deze definitie moeten hieronder worden verstaan repotransacties, effecten- en grondstoffenleningen, buy-sell backs en sell-buy backs en margeleningstransacties.

21. Een omnibusrekening is een rekening waarop financiële instrumenten voor rekening en risico van verschillende partijen worden aangehouden, al dan niet met inbegrip van financiële instrumenten die aan de rekeninghouder zelf toekomen. 
overdracht met niet-professionele beleggers nader uit door te bepalen dat de lidstaten erop zullen moeten toezien dat beleggingsondernemingen geen door art. 16 lid 10 MiFID II verboden overeenkomsten sluiten. Ook met professionele cliënten mag een dergelijke overeenkomst echter niet zomaar worden aangegaan: art. 6 MiFID II-Uitvoeringsrichtlijn stelt strenge eisen aan het aangaan door een beleggingsonderneming van een dergelijke overeenkomst met een professionele cliënt. Deze mag alleen worden aangegaan als de beleggingsonderneming kan aantonen dat deze overeenkomst past in de relatie met de cliënt (appropriateness test) en zij de cliënt heeft gewezen op de risico's en de gevolgen van het gebruik van dit zekerheidsinstrument voor de aan de cliënt toebehorende financiële instrumenten en gelden. Factoren die in dit verband moeten worden meegewogen, zijn de relatie tussen de verplichtingen van de cliënt en het gebruik van de FZO tot overdracht als zekerheidsinstrument, de waarde van het onderpand in verhouding tot de verplichtingen van de cliënt en de vraag of de beleggingsonderneming altijd gebruik maakt van het instrument van de FZO tot overdracht, ongeacht welke verplichtingen een individuele cliënt jegens de beleggingsonderneming heeft. Deze nieuwe voorschriften houden direct verband met vermogensscheiding, omdat een FZO tot overdracht de eigendom van aan cliënten toebehorende financiële instrumenten en gelden doet overgaan op de beleggingsonderneming. ${ }^{22}$

Nieuw is ook de in art 7. MiFID II-Uitvoeringsrichtlijn opgenomen verplichting voor de beleggingsonderneming om een 'asset segregation officer' (ASO) te benoemen. Dit is een functionaris die binnen de beleggingsonderneming de verantwoordelijkheid heeft voor de naleving van de regels inzake de bescherming van de financiële instrumenten en gelden van clienten. Het doel van het aanwijzen van een dergelijke functionaris is om het risico te beperken dat de verantwoordelijkheid voor vermogensscheiding versnipperd raakt over verschillende afdelingen, vooral in grote en complexe ondernemingen. De ASO moet beschikken over voldoende vaardigheden en gezag om zijn taken daadwerkelijk en ongehinderd te vervullen, ook wanneer hij aan de leiding van de onderneming moet rapporteren over de vervulling van zijn werkzaamheden en of de onderneming voldoet aan haar verplichtingen inzake de vrijwaring en het niet-gebruiken van activa van cliënten.

Art. 8 MiFID II-Uitvoeringsrichtlijn bevat de onder MiFID reeds bestaande regel dat de beleggingsonderneming eens per jaar aan de bevoegde toezichthouder een verslag van een externe accountant moet overleggen over de naleving van de toepasselijke vermogensscheidingsregels. Uit dit verslag dient te blijken dat de beleggingsonderneming in overeenstemming met deze regels heeft gehandeld.

22. Zie over dit verbod en de consequenties ervan voor de praktijk uitvoerig: Rank \& Uiterwijk 2018.

\subsection{Europese toezichtregelgeving vermogensscheiding: \\ MiFID II-Uitvoeringsverordening 2017/565}

Art. 49 MiFID II-Uitvoeringsverordening 2017/565 bevat een aantal door de beleggingsonderneming jegens haar cliënten op het punt van de bewaring van financiële instrumenten en gelden in acht te nemen informatieverplichtingen. Zo is de beleggingsonderneming gehouden informatie te verstrekken over (1) de omstandigheid dat financiële instrumenten of gelden die aan de belegger toebehoren door de beleggingsonderneming bij een derde kunnen worden aangehouden, (2) de wettelijke verantwoordelijkheid van de beleggingsonderneming voor de handel en wandel van een dergelijke derde en een faillissement van deze laatste, (3) de risico's van bewaring op een omnibusrekening, (4) de onmogelijkheid van identificatie door de derde van aan de belegger toebehorende financiële instrumenten en de risico's daarvan, (5) de mogelijke toepasselijkheid van het recht van een niet-EU/EER-lidstaat en de consequenties daarvan, en (6) de aan de beleggingsonderneming of aan de door deze ingeschakelde derde toekomende goederenrechtelijke zekerheidsrechten, voorrechten en verrekeningsrechten, alsmede (7) de juridische consequenties en risico's van het ter beschikking stellen door de cliënt van de voor hem gehouden financiële instrumenten voor effectenfinancieringstransacties. Onder MiFID waren deze verplichtingen opgenomen in art. $32 \mathrm{MiFID-Uitvoeringsrichtlijn.} \mathrm{Onder}$ MiFID II zijn ze ondergebracht in de MiFID II-Uitvoeringsverordening $2017 / 565$. Als gevolg daarvan hebben deze informatieverplichtingen rechtstreekse werking en zijn ze niet meer in nationale regelgeving geïmplementeerd. Het onderscheid dat in art. 32 MiFID-Uitvoeringsrichtlijn nog werd gemaakt tussen professionele beleggers en niet-professionele beleggers is in art. 49 MiFID II-Uitvoeringsverordening 2017/565 komen te vervallen.

De vermogensscheidingsregels van MiFID II gelden niet alleen voor beleggingsondernemingen, maar ook voor banken die beleggingsdiensten verlenen. ${ }^{23}$ Indirect zijn de vermogensscheidingsregels van MiFID II ook van toepassing op beleggingsinstellingen. Zowel de AIFMD ${ }^{24}$ als UCITS $\mathrm{V}^{25}$ vereist dat de activa van een beleggingsinstelling moeten worden bewaard door een onafhankelijke bewaarder, en dat deze bewaarder deze activa moet afscheiden van zijn eigen activa met inachtneming van de zojuist besproken MiFID-regels. Art. 21 lid 8 sub a onderdeel ii AIFMD bepaalt in dit verband dat de bewaarder ervoor zorgt dat alle financiële instrumenten die kunnen worden geregistreerd op een financiële-instrumentenrekening in de boeken van de bewaarder, in deze boeken op

23. Art. 1 lid 3 sub a MiFID II.

24. Richtlijn 2011/61/EU van het Europees Parlement en de Raad inzake beheerders van alternatieve beleggingsinstellingen en tot wijziging van de Richtlijnen 2003/41/EG en 2009/65/EG en van de Verordeningen (EG) 1060/2009 en (EU) 1095/2010, PbEU 1 juli 2011, L 174/1.

25. Richtlijn 2014/91/EU van het Europees Parlement en de Raad van 23 juli 2014 tot wijziging van Richtlijn 2009/65/EG tot coördinatie van de wettelijke en bestuursrechtelijke bepalingen betreffende bepaalde instellingen voor collectieve belegging in effecten (icbe's) wat bewaartaken, beloningsbeleid en sancties betreft, PbEU 28 augustus 2014, L 257/186. 


\section{Maandblad \\ Vermogensrecht}

aparte rekeningen worden geregistreerd, in overeenstemming met de beginselen vastgelegd in art. 16 Richtlijn 2006/73/EG, welke aparte rekeningen zijn geopend op naam van de AIF of op naam van de AIF-beheerder die namens de AIF optreedt, zodat te allen tijde duidelijk kan worden vastgesteld dat zij conform de toepasselijke wetgeving toebehoren aan de AIF. ${ }^{26}$ Art. 22 lid 5 sub a onderdeel ii UCITS V bepaalt hetzelfde voor een ICBE.

\subsection{Europese toezichtregelgeving vermogensscheiding: EMIR}

Bepalingen ter bescherming van financiële instrumenten van cliënten tegen het tussenpersoonrisico vinden we behalve in MiFID II ook in de Verordening betreffende OTC-derivaten, centrale tegenpartijen en transactieregisters (European Market Infrastructure Regulation, beter bekend als EMIR). ${ }^{27}$ Weliswaar ziet MiFID II op alle financiële instrumenten, maar de vermogensscheidingsregels van MiFID II zijn toch vooral geschreven vanuit de optiek van de afscheiding van traditionele financiële instrumenten, effecten in de klassieke zin des woords. Bij EMIR staat de bescherming van de derivatenbelegger centraal. EMIR voorziet onder meer in een verplichting tot clearing van bepaalde typen OTC-derivatencontracten via een centrale tegenpartij (central counterparty, CCP). Clearing door een CCP houdt kort gezegd in dat de wederpartijen bij een OTC-derivatencontract hun wederzijdse tegenpartijkredietrisico vervangen door een tegenpartijkredietrisico op een CCP. Daartoe worden de wederzijdse rechten en verplichtingen van de wederpartijen bij het OTC-derivatencontract vervangen door corresponderende rechten en verplichtingen ten opzichte van de CCP. De CCP plaatst zich dus als het ware 'tussen' de oorspronkelijke wederpartijen. ${ }^{28}$ Alleen kapitaalkrachtige marktpartijen kunnen echter directe toegang krijgen tot een centrale tegenpartij. Om minder kapitaalkrachtige marktpartijen te faciliteren treden er daarom in het clearingproces vaak ook één of meer tussenpersonen op. Een beleggingsonderneming die als tussenpersoon fungeert en daadwer-

26. Zie hierover nader W.A.K. Rank, Een beleggingsfonds in de vorm van een FGR: een meerpartijenovereenkomst sui generis?, in: C.G. Breedveld-de Voogd e.a. (red.), De meerpartijenovereenkomst, BWKJ 29, Deventer: Wolters Kluwer 2015, p. 150-152, volgens wie een dergelijke rekening in het geval van een beleggingsfonds in de vorm van een FGR moet worden geopend in naam van de bewaarentiteit.

27. Verordening (EU) 648/2012 van het Europees Parlement en de Raad van 4 juli 2012 betreffende otc-derivaten, centrale tegenpartijen en transactieregisters. Zie voor een uitvoerige beschrijving van EMIR o.m. F.G.B. Graaf \& R.A. Stegeman, Regulering van de OTC-derivatenmarkten in de EU en de VS (preadvies Vereniging voor Effectenrecht 2011; Serie vanwege het Van der Heijden Instituut, deel 111), Deventer: Kluwer 2011, p. 63-104 en B.J.A. Zebregs, Effecten- en derivatenclearing (Financieel Juridische Reeks 5), Amsterdam: NIBE-SVV 2013, p. 215-240 en 263-290.

28. Zie over (derivaten)clearing o.m. S.R. van Leijenhorst \& F.W. Wendt, Afwikkelondernemingen in financiële instrumenten, in: D. Busch e.a. (red.), Onderneming en financieel toezicht (Serie Onderneming en Recht, deel 57), Deventer: Kluwer 2010, p. 361-392, L.J. Silverentand \& P. Heemskerk, Clearing: kern- en knelpunten, in: S.E. Bartels, A.J. Verdaas \& R.J. van der Weijde (red.), Effecten en vermogensrecht (Serie Onderneming en Recht, deel 63), Deventer: Kluwer 2011, p. 239-261 en Zebregs 2013, p. 17-143. kelijk is aangesloten bij de CCP - de hoogste schakel in de clearingketen - wordt in dit verband meestal aangeduid als clearinglid (clearing member, CM). Dit zijn doorgaans grotere financiële ondernemingen, met name banken. ${ }^{29}$ Een CM staat op zijn beurt weer tussen de CCP en de oorspronkelijke wederpartij bij het geclearde derivaat, of - in het geval van indirecte clearing - tussen de CCP en een eerder in de keten door de oorspronkelijke wederpartij ingeschakelde tussenpersoon. ${ }^{30}$

Ter bescherming van de derivatenposities van een eindgebruiker (cliënt) en de door deze gestelde zekerheden in het geval van een faillissement of het anderszins in gebreke blijven van de CM bevat EMIR voorschriften inzake gescheiden rekeningen voor derivatenposities en zekerheden van een cliënt of van meerdere cliënten (individuele respectievelijk omnibussegregatie; art. 39 EMIR) en de mogelijke overdracht door een CCP van de door een in gebreke blijvende CM voor één of meer clienten gehouden derivatenposities en zekerheden naar een andere CM (portabiliteit; art. 48 EMIR). ${ }^{31}$ Deze regels richten zich tot de CCP en de CM en zien overigens uitsluitend op de derivatenposities en zekerheden die door een CM bij de CCP worden aangehouden ten behoeve van cliënten, niet op de derivatenposities en zekerheden die door een cliënt bij de $\mathrm{CM}$ worden aangehouden. ${ }^{32}$

29. Een clearinglid is niet altijd een clearinginstelling als bedoeld in art. 1:1 Wft. Deze laatste houdt zich blijkens de definitie alleen bezig met het clearen van transacties die op een handelsplatform tot stand zijn gekomen, en dus niet met OTC-derivaten. Met het van kracht worden van de handelsverplichting van art. $28 \mathrm{MiFIR}$ echter zullen transacties in derivaten waarvoor onder EMIR een verplichting tot clearing geldt, in beginsel moeten plaatsvinden op een handelsplatform en daarmee voor clearing door een clearinginstelling in aanmerking kunnen komen. ESMA heeft op haar website een register gepubliceerd waarin de desbetreffende OTCderivaten en handelsplatformen worden vermeld.

30. In het geval er meerdere tussenpersonen optreden, wordt gesproken over indirecte clearing. Voor meer informatie over indirecte clearing zie o.m. R.A. Stegeman \& B.J.A. Zebregs, Enkele kanttekeningen bij indirecte clearing, FR 2014, afl. 5, p. 171 en C.A.R. Oudhuis, Indirecte clearing verhelderd, MvV 2016, afl. 4, p. 97-104.

31. Het gaat hier om zekerheden (collateral of margin) die worden verstrekt ter dekking van verplichtingen die voortvloeien uit derivatenposities. EMIR spreekt in dit verband van activa (assets). EMIR bepaalt in art. 39 lid 10 dat onder 'activa' een zekerheid wordt verstaan die ter dekking van derivatenposities wordt aangehouden. Hierna wordt gemakshalve gesproken over zekerheden.

32. Art. 39 en 48 EMIR zijn ook niet van toepassing op de derivatenposities en zekerheden die, in het geval van een indirecte clearingregeling, door een cliënt (in feite ook een tussenpersoon) voor een indirecte cliënt bij de $\mathrm{CM}$ worden aangehouden, of op de derivatenposities en zekerheden die door een indirecte cliënt bij de cliënt worden aangehouden. De vereisten die gelden voor indirecte clearing, waaronder die met betrekking tot segregatie en portabiliteit, zijn uitgewerkt in de Gedelegeerde Verordening (EU) 149/2013 van de Commissie van 19 december 2012 tot aanvulling van Verordening (EU) 648/2012 van het Europees Parlement en de Raad met technische reguleringsnormen betreffende indirecte clearingregelingen, de clearingverplichting, het openbaar register, toegang tot een handelsplatform, niet-financiële tegenpartijen en risico-inperkingstechnieken voor niet door een CCP geclearde otc-derivatencontracten, PbEU 23 februari 2013, L 52/11. 


\section{Maandblad Vermogensrecht}

Aan het vereiste om derivatenposities en zekerheden in de rekeningen van de CCP gescheiden te houden wordt geacht te zijn voldaan, indien (1) de posities en zekerheden zijn vastgelegd in gescheiden rekeningen, (2) het verrekenen van op verschillende rekeningen vastgelegde posities wordt voorkomen, en (3) de zekerheden die de posities dekken die in een rekening zijn vastgelegd, niet blootstaan aan verliezen die verband houden met posities die in een andere rekening zijn vastgelegd (art. 39 lid 9 EMIR). De vraag is of hiermee wordt voorzien in een verplichting tot juridische segregatie - vermogensscheiding - of slechts in een verplichting tot administratieve segregatie. In het geval van juridische segregatie zijn de voor een client gehouden posities en zekerheden afgescheiden van de posities en zekerheden van de CM zelf en van die van andere cliënten. De betreffende posities en zekerheden behoren dan in juridische zin toe aan de cliënt of zijn uitsluitend vatbaar voor verhaal door de cliënt en niet voor verhaal door (andere) crediteuren van de CM. In het geval van administratieve segregatie zijn de voor een cliënt gehouden posities en zekerheden alleen operationeel afgescheiden van de posities en zekerheden van de CM zelf en, in het geval van individuele segregatie, van die van andere cliënten van de CM.

Art. 39 lid 9 EMIR bepaalt niet meer dan dat posities op verschillende rekeningen niet met elkaar mogen worden gesaldeerd en dat onderpand alleen mag worden aangewend ter dekking van verliezen op de door dit onderpand gesecureerde posities. Dit impliceert dat EMIR op dit moment niet vereist dat de posities en zekerheden die worden aangehouden ten behoeve van cliënten buiten het vermogen van de CM vallen. Naar het lijkt vereist EMIR op dit moment dan ook slechts een vorm van administratieve (operationele) segregatie, waarbij het gaat om het kunnen identificeren van derivatenposities en zekerheden van één (individuele segregatie) of meer (omnibussegregatie) cliënten van een CM, niet een juridische segregatie. ${ }^{33}$ Deze zienswijze wordt ondersteund door het feit dat de Nederlandse wetgever het nodig heeft geacht in de Wge te moeten voorzien in een juridische segregatie (waarover hierna par. 4.3) en door het op 4 mei 2017 door de Europese Commissie gepubliceerde voorstel tot wijziging van EMIR. Onderdeel van dit voorstel is onder meer de toevoeging aan art. 39 EMIR van een nieuw lid 11. Volgens deze bepaling zullen de derivatenposities en zekerheden die door een CM conform de segregatievoorschriften in EMIR voor haar cliënten in rekeningen bij een CCP zijn vastgelegd, niet worden beschouwd als onderdeel van de insolvente boedel van de CCP of de CM. ${ }^{34}$ Overigens is het huidige art. 39 lid 9 zo opgesteld dat het

33. Aldus: Rank 2014, p. 217-218; Rank \& Uiterwijk 2017, p. 376-377. Het zal primair afhangen van het toepasselijke internationaal privaatrecht, met name het recht dat op de CM en de door haar aangehouden derivatenposities en zekerheden van cliënten van toepassing is, of de administratieve segregatie ook van rechtswege resulteert in een juridische segregatie.

34. Zie over dit voorstel kritisch: Rank \& Uiterwijk 2017, p. 376-377. Inmiddels hebben verschillende nieuwe tekstvoorstellen het licht gezien, maar van een consistente lijn is daarbij geen sprake. qua gevolgen niet veel zal verschillen van een situatie waarin sprake is van juridische segregatie.

De segregatie is van belang voor het kunnen realiseren van portabiliteit van de derivatenposities en zekerheden. Portabiliteit wil zeggen dat de derivatenposities en zekerheden die bij de CCP worden aangehouden in het geval een CM in gebreke blijft door de CCP moeten kunnen worden overgedragen aan een andere CM (een back-up-CM). Indien de overdracht van derivatenposities en zekerheden naar de back-up-CM niet binnen de daarvoor in de regels van de CCP bepaalde periode plaatsvindt, mag de CCP overgaan tot vereffening (afwikkeling) van die posities en zekerheden. ${ }^{35}$ Omdat het clearingproces in de Europese markt wordt gekenmerkt door principal-toprincipal-verhoudingen, waarbij de cliënt optreedt jegens de $\mathrm{CM}$ en de CM jegens de CCP en er (dus) doorgaans geen directe rechtsverhouding tussen de cliënt en de CCP ontstaat, rijst de vraag of en in hoeverre het Nederlandse faillissementsrecht (en dat van andere lidstaten) hiermee verenigbaar is, althans door EMIR opzij wordt gezet. Een kernbeginsel van het Nederlandse faillissementsrecht is immers dat een gefailleerde CM, zodra haar faillissement is ingetreden, niet meer over haar rechten en verplichtingen kan beschikken, laat staan dat een crediteur, zoals een CCP of cliënt, dat zou kunnen. ${ }^{36}$ Aangenomen dat een CM posities uit hoofde van OTC-derivatencontracten en bepaalde zekerheden voor haar cliënt(en) bij een CCP aanhoudt, betekent dit in principe dat dergelijke posities en zekerheden, althans de opbrengsten, in het geval van vereffening in de failliete boedel van de CM vallen.

Er zijn zeker argumenten om te betogen dat het Nederlandse faillissementsrecht de portabiliteitsregeling uit EMIR niet kan (of zou moeten kunnen) doorkruisen. Hiervoor pleit vooral dat EMIR een Europese verordening is die rechtstreekse werking heeft in elke lidstaat en voorrang heeft boven het nationale recht van een lidstaat. ${ }^{37}$ Niettemin kan niet worden uitgesloten dat een curator van een CM niet aan de overdracht wil meewerken, althans dat een Nederlandse rechter met de verordening strijdige bepalingen van Nederlands recht niet buiten toepassing zou laten. ${ }^{38}$ Hierdoor kan op z'n minst vertraging ontstaan, hetgeen al een (ongewenste) belemmering voor het realiseren van portabiliteit vormt. Bovendien strekt de regeling zich niet uit tot de posities en zekerheden die een cliënt jegens de CM zou kunnen uitoefenen. Dergelijke posities en zekerheden zouden hoe dan ook in de failliete boedel van de

35. Art. 48 lid 5 en 6, laatste volzin, EMIR.

36. Art. 23, 24 en $35 \mathrm{Fw}$.

37. HvJ EG 15 juli 1964, C-6/64, ECLI:EU:C:1964:66. Zie ook overweging 64 EMIR. Daarin staat onder meer: '[d]e in deze verordening neergelegde eisen inzake het gescheiden houden en de overdraagbaarheid van de posities en activa van leden dienen derhalve voorrang te hebben op eventueel tegenstrijdige nationale wetten, regels en bestuursrechtelijke bepalingen die de partijen verhinderen deze eisen na te leven'.

38. Een tegenargument zou kunnen worden ontleend aan art. 48 lid 5 en 6 EMIR, waarin staat dat de CCP zich (ten minste) contractueel dient te verbinden aan de portabiliteitsregeling, op basis waarvan men zich zou kunnen afvragen of voorrang boven nationaal faillissementsrecht is beoogd. Vgl. Rank 2014, p. 220 en Rank \& Uiterwijk 2017, p. 376-377. 
CM vallen, en de cliënt noch de CCP zou daarover kunnen beschikken voor portabiliteitsdoeleinden.

Om mogelijke twijfels weg te nemen omtrent de werking van de in EMIR voorziene regels inzake segregatie en portabiliteit voorziet de Wge sinds 1 april 2016 in een regeling tot bescherming van derivatenbeleggers tegen het faillissement van tussenpersonen. Deze regeling komt aan de orde in paragraaf 4.3.

\subsection{Europese toezichtregelgeving vermogensscheiding: CSD-verordening}

Voorschriften inzake (administratieve) segregatie zijn ook opgenomen in de CSD-verordening. ${ }^{39}$ Deze voorschriften richten zich tot centrale effectenbewaarinstellingen (central securities depositories, CSDs) en aangesloten instellingen en strekken tot bescherming van effecten van die aangesloten instellingen en die van hun cliënten. De voorschriften zijn neergelegd in art. 38 CSD-verordening en stemmen, althans op het eerste gezicht, in verschillende opzichten overeen met de segregatiebepalingen van art. 39 EMIR. ${ }^{40}$

Een CSD moet voor elk effectenafwikkelingssysteem dat zij exploiteert vastleggingen en rekeningen aanhouden die haar in staat stellen te allen tijde en onverwijld de effecten van elke aangesloten instelling te scheiden van die van elke andere aangesloten instelling en van de eigen activa van de CSD (art. 38 lid 1 CSD-verordening). Ook dient een CSD vastleggingen en rekeningen aan te houden die elke aangesloten instelling in staat stellen om haar eigen effecten te scheiden van die van haar cliënten (art. 38 lid 2 CSD-verordening). Daartoe moet een CSD een aangesloten instelling in elk geval de mogelijkheid bieden om de effecten van de verschillende cliënten van de aangesloten instelling op geconsolideerde basis aan te houden in één rekening in de boeken van de CSD (omnibussegregatie) (art. 38 lid 3 CSD-verordening). Indien en voor zover vereist door een aangesloten instelling moet een CSD die aangesloten instelling echter ook de mogelijkheid bieden om de effecten van de verschillende cliënten van de aangesloten instelling aan te houden in evenzovele afzonderlijke rekeningen in de boeken van de CSD (individuele segregatie) (art. 38 lid 4 CSD-verordening). De aangesloten instellingen zijn verplicht om hun cliënten ten minste de keuze te bieden tussen omnibussegregatie en individuele segregatie en hen te informeren omtrent de aan beide opties verbonden kosten en risico's (art. 38 lid 5 CSD-verordening). CSDs en aangesloten instellingen moeten publiekelijk bekendmaken welk beschermings-

39. Verordening (EU) 909/2014 van het Europees Parlement en de Raad van 23 juli 2014 betreffende de verbetering van de effectenafwikkeling in de Europese Unie, betreffende centrale effectenbewaarinstellingen en tot wijziging van Richtlijnen 98/26/EU en 2014/65/EU en Verordening (EU) 236/2012, PbEU 28 augustus 2014, L 257/1-72. De CSD-verordening is sinds 17 september 2014 van kracht en voorziet in een gefaseerde inwerkingtreding van een antal verplichtingen voor CSDs en aangesloten instellingen.

40. Een belangrijk verschil tussen beide regelingen is dat EMIR, anders dan de CSD-verordening, weliswaar niet de iure, maar wel de facto in juridische segregatie voorziet (door de bepaling van art. 39 lid 9 EMIR) en een portabiliteitsregeling bevat. niveau en welke kosten verbonden zijn aan de verschillende vormen van segregatie en moeten de verschillende varianten tegen redelijke commerciële voorwaarden aanbieden. De met betrekking tot de verschillende segregatieniveaus te publiceren informatie dient een beschrijving te omvatten van de belangrijkste juridische implicaties, met inbegrip van informatie over het insolventierecht dat in het relevante rechtsgebied van kracht is (art. 38 lid 6 CSD-verordening). Ook bepaalt de CSD-verordening dat een CSD geen gebruik mag maken van effecten die haar niet toebehoren. $\mathrm{Zij}$ mag effecten van een aangesloten instelling gebruiken als zij daarvoor voordien de uitdrukkelijke toestemming van de aangesloten instelling heeft verkregen. De aangesloten instelling moet daaraan voorafgaand wel de toestemming van de cliënt hebben verkregen (art. 38 lid 7 CSD-verordening).

Evenals in het geval van EMIR rijst onder de CSD-verordening de vraag of de verordening een verplichting tot juridische segregatie - vermogensscheiding - behelst of dat zij slechts tot administratieve segregatie verplicht. De in art. 38 CSD-verordening gehanteerde terminologie wijst op het eerste gezicht in de richting van een verplichting tot juridische segregatie. Een aanwijzing daarvoor is allereerst het gebruik van de term 'vermogensscheiding' in art. 38 lid $4 \mathrm{t} / \mathrm{m} 6$ van de Nederlandstalige versie van de CSD-verordening. Een andere indicatie is de kennelijk aan de bepaling van art. 38 lid 6 ten grondslag liggende gedachte dat de verschillende vormen van segregatie in een verschillend beschermingsniveau voor cliënten zouden resulteren. Die gedachte vinden we ook terug in overweging 42 van de considerans van de CSD-verordening. Daarin wordt aangegeven dat de segregatievereisten zijn opgenomen met het oog op een betere bescherming van de activa van de aangesloten instellingen en die van hun cliënten. Ook het kopje van art. 38 CSD-verordening bedient zich van dergelijke bewoordingen. Wat mij betreft lijdt het echter geen twijfel dat de CSD-verordening slechts tot administratieve segregatie verplicht en niet tot juridische segregatie. Om te beginnen wordt in de eerdergenoemde overweging 42 van de considerans met zoveel woorden gezegd dat de CSD-verordening het nationale recht van de lidstaten betreffende het houderschap van effecten niet mag doorkruisen. ${ }^{41}$ Verder geeft de CSD-verordening op geen enkele wijze aan dat de in de gesegregeerde rekeningen aangehouden financiële instrumenten niet mogen worden beschouwd als deel van de insolvente boedel van een CSD of een aangesloten instelling. Ook wordt nergens in de CSD-verordening bepaald dat de in deze rekeningen geadministreerde effecten afgescheiden vermogens constitueren en ook niet wie daarop verhaal zou kunnen nemen of daarover zou kunnen beschikken. Ten slotte bevat de CSD-verordening ook geen met art. 39 lid 9 EMIR overeenkomende of vergelijkbare bepaling.

Het belangrijkste argument is wat mij betreft echter gelegen in de in MiFID II voorziene regeling van de juridische segregatie.

41. In de Engelstalige versie: 'This Regulation should not interfere with the national law of the Member States regarding the holdings of securities.' 
Niet voor niets laat MiFID II de wijze waarop beleggingsondernemingen de voor hun cliënten gehouden financiële instrumenten juridisch van hun eigen activa moeten afscheiden over aan de nationale wetgeving van de lidstaten. De gedachte daarachter is dat daarbij rekening kan worden gehouden met eigenaardigheden van nationaal goederenrecht. Het zou bizar zijn als deze aanpak voor bepaalde beleggingsondernemingen - beleggingsondernemingen die kwalificeren als aangesloten instellingen bij een CSD - door de CSD-verordening zou worden doorkruist met voorbijgaan aan nationaal goederenen faillissementsrecht. Dit argument ligt in het verlengde van het in overweging 42 van de considerans gestelde over het primaat van het nationale recht betreffende het houderschap van effecten. Daarbij komt nog dat in de Engelstalige versie van de CSD-verordening niet wordt gesproken van 'legal segregation', maar simpelweg van 'segregation', welk begrip niet noodzakelijkerwijs op juridische segregatie betrekking hoeft te hebben. Verder hoeft de betere bescherming van de activa van aangesloten instellingen en hun cliënten niet per se te zien op een betere juridische bescherming. Deze bescherming kan ook hierin bestaan dat door het aanhouden van verschillend getitelde rekeningen in de boeken van de CSD bij insolventie van de aangesloten instelling sneller kan worden vastgesteld aan wie bepaalde effecten toebehoren. Het moet er dan ook voor worden gehouden dat de CSD-verordening, net als EMIR, slechts tot administratieve segregatie verplicht. ${ }^{42}$

Mogelijk zal deze administratieve segregatie in bepaalde jurisdicties ook in juridische segregatie resulteren. In Nederland is daarvan echter geen sprake. De in de CSD-verordening aan de CSD en de aangesloten instellingen opgelegde segregatieverplichtingen voegen materieel niets toe aan de door de Wge geboden bescherming. Effecten die een cliënt bij een aangesloten instelling van Euroclear Nederland in bewaring heeft gegeven, worden door de Wge beschermd tegen de insolventie van de aangesloten instelling, ongeacht of deze effecten door de aangesloten instelling bij Euroclear Nederland worden aangehouden in een rekening waarin zowel eigen effecten van de aangesloten instelling als effecten van cliënten van de aangesloten instelling worden geadministreerd, in een rekening waarin alleen effecten van cliënten van de aangesloten instelling worden geadministreerd, echter op geconsolideerde basis, of in afzonderlijke rekeningen met betrekking tot iedere individuele cliënt. Zoals in paragraaf 4 nader zal worden uiteengezet, is het systeem van de Wge erop gebaseerd dat de rekeningen in de boeken van Euroclear Nederland luiden op naam van de aangesloten instelling. Weliswaar behoren de in deze rekeningen geadministreerde effecten toe aan de cliënten van de desbetreffende aangesloten instelling, maar het uitgangspunt van de Wge is dat een cliënt zijn rechten met betrekking tot deze effecten uitsluitend geldend kan maken via de aangesloten

42. Aldus op vergelijkbare gronden ook: B.J.A. Zebregs, De CSD-verordening in het licht van de Capital Markets Union, Ondernemingsrecht 2017/18, p. 120-131. Steun voor deze opvatting is te vinden in de Q\&A van ESMA met betrekking tot de CSD-verordening van 23 maart 2018, met name in antwoord op vraag 5, p. 17-18. instelling. Voegen de in de CSD-verordening neergelegde segregatieverplichtingen materieel niets toe aan de door de Wge geboden bescherming, dat neemt niet weg dat Euroclear Nederland en de aangesloten instellingen zich wel aan deze verplichtingen zullen hebben te houden.

Op grond van de CSD-verordening is Euroclear Nederland derhalve verplicht om in haar boeken per aangesloten instelling gescheiden rekeningen te openen voor respectievelijk de eigen effecten van de aangesloten instelling en de effecten van cliënten van de aangesloten instelling en, indien en voor zover vereist door een aangesloten instelling, ook afzonderlijke rekeningen voor de effecten van individuele cliënten van de aangesloten instelling. Aangesloten instellingen moeten hun cliënten de mogelijkheid bieden om te kiezen in welk type rekening zij hun effecten op CSD-niveau opgenomen willen zien: in een omnibusrekening, waarin effecten van verschillende cliënten van de aangesloten instelling op geconsolideerde basis worden geadministreerd, of in een afzonderlijke rekening, waarin alleen de effecten van de desbetreffende cliënt worden geadministreerd. Uit de tekst van de CSD-verordening kan mijns inziens niet worden opgemaakt dat genoemde rekeningen in de boeken van de CSD moeten luiden op naam van de (gezamenlijke) cliënten van de aangesloten instelling of op naam van een individuele cliënt van de aangesloten instelling. De gebruikte bewoordingen laten ook toe dat de rekeningen luiden op naam van de aangesloten instelling, in het geval van omnibussegregatie bijvoorbeeld met de toevoeging inzake clienten' en in het geval van individuele segregatie bijvoorbeeld met de toevoeging 'inzake cliënt $\mathrm{X}$ '. Deze wijze van tenaamstelling past ook bij de bestaande praktijk van de meeste CSDs, waarbij de CSD de cliënten van de aangesloten instelling niet kent en ook niet wil kennen, en de rechten van een cliënt altijd worden uitgeoefend via de aangesloten instelling. Het gaat erom dat de effecten van cliënten van de aangesloten instelling zijn te (onder)scheiden van de eigen effecten van de aangesloten instelling en, desgewenst, van de effecten van andere cliënten van de aangesloten instelling. Dat lijkt ook mogelijk in een rekeningstructuur waarbij sprake is van inzake-rekeningen of subaccounts. Uiteraard is het daarbij steeds aan het recht van het land waar de rekeningen worden aangehouden om te bepalen wat de juridische consequenties van de gebruikte tenaamstelling zijn.

De omstandigheid dat art. 38 CSD-verordening niet tot juridische segregatie verplicht en de omstandigheid dat administratieve segregatie zoals voorzien in art. 38 CSD-verordening naar Nederlands recht in ieder geval niet in juridische segregatie resulteert, hebben uiteraard consequenties voor het op grond van art. 38 lid 6 CSD-verordening te publiceren cliëntinformatiedocument. Art. 38 lid 6 CSD-verordening gaat uit van de gedachte dat de verschillende in art. 38 CSD-verordening voorziene vormen van segregatie in een verschillend beschermingsniveau voor cliënten resulteren. Nu cliënten op grond van de Wge ook worden beschermd tegen insolventie van de aangesloten instelling als zij hebben gekozen voor het 


\section{Maandblad}

aanhouden door de aangesloten instelling van hun effecten in een omnibuseffectenrekening bij de CSD in plaats van in een individuele effectenrekening, zal in het cliëntinformatiedocument tot uitdrukking moeten worden gebracht dat de verschillende wijzen waarop de effecten van cliënten op het niveau van Euroclear Nederland worden geadministreerd juridisch niet tot een verschil in bescherming leiden. Dat geldt ook in het geval dat cliënten van een aangesloten instelling die effecten van dezelfde soort bezitten, gezamenlijk meer effecten van die soort aanhouden bij de aangesloten instelling dan de aangesloten instelling bij Euroclear Nederland. Er is dan sprake van een tekort in het verzameldepot. Bij verdeling van het depot krijgt de cliënt dan niet al zijn effecten terug, maar slechts een deel daarvan, naar evenredigheid van zijn aandeel in het depot. Daarvoor maakt het geen verschil of de effecten op CSD-niveau worden geadministreerd in een omnibuseffectenrekening of in een individuele effectenrekening.

Een voordeel van individuele segregatie op CSD-niveau zou kunnen zijn dat daardoor bij insolventie van de aangesloten instelling sneller kan worden vastgesteld aan wie bepaalde effecten toebehoren. Dit betekent echter niet dat een curator ook sneller tot vrijgave van de in een individuele effectenrekening geadministreerde effecten zal kunnen overgaan. De curator zal immers ook rekening moeten houden met de Wgeregeling voor tekorten in een verzameldepot en de belangen van andere effectenrekeninghouders. Een nadeel is waarschijnlijk dat individuele segregatie op CSD-niveau de afwikkeling van transacties bemoeilijkt en kostbaarder maakt. Een mogelijk gevolg is ook een grotere transparantie van aandeelhoudersbelangen en zeggenschap. De ene cliënt zal dat als een voordeel ervaren, maar de andere cliënt juist niet. Deze en andere punten zouden in het cliëntinformatiedocument kunnen worden opgenomen teneinde de cliënten in staat te stellen een verantwoorde keuze te maken tussen omnibussegregatie en individuele segregatie op CSD-niveau.

In verband met de omvang wordt dit artikel in twee delen gepubliceerd. Tot zover het eerste deel. Hierin kwam naast de inleiding (par. 1) een beschrijving van de Europese toezichtregels op het punt van de vermogensscheiding (par. 2) aan de orde. Het tweede deel - te verschijnen in MvV 2018, afl. 6 - beschrijft de Nederlandse toezichtregels en de privaatrechtelijke regeling van de vermogensscheiding en hoe de beide soorten rechtsregels zich tot elkaar verhouden (par. 3 t/m 5). Dit deel bevat ook de samenvatting en de conclusie (par. 6). Omdat sprake is van één geïntegreerd artikel zijn de paragrafen en subparagrafen van de beide delen doorlopend genummerd. 